\title{
Comparison of rimonabant and sibutramine treatment effects on food compulsion in rats ${ }^{1}$
}

\author{
Comparação do efeito do rimonabanto e da sibutramina no tratamento da compulsão alimentar \\ em ratos
}

\author{
Honório Sampaio Menezes, Verônica CiullaII, Paulo Sampaio Camargo ${ }^{\mathrm{III}}$, Cora Albrecht Correa ${ }^{\mathrm{III}}$, Tatiana Medina Costa de \\ Oliveira $^{\text {III }}$
}

\author{
${ }^{I} \mathrm{PhD}$, Assistant Professor, Cardiology University Foundation (IC/FUC), Porto Alegre, and ULBRA, Canoas - RS, Brazil. \\ ${ }^{\text {II }}$ Researcher of Experimental Medicine Group, ULBRA, Canoas - RS, Brazil. \\ III Graduate Student, Experimental Medicine Group, ULBRA, Canoas - RS, Brazil.
}

\begin{abstract}
Purpose: To compare the therapeutic effect of rimonabant, a new drug which is a selective antagonist of CB1 receptors, with the sibutramine. Methods: It is an experimental clinical trial, prospective, placebo controlled. Our test was performed in 38 rats, adults females with a hyper caloric diet. We collected their blood 3 times and weighted them once a week. We divided the rats in 3 groups: Rimonabant, Sibutramine and Control. Statistic analysis has been made through ANOVA test, Tukey test and $t$ Student test. Results: The Rimonabant group demonstrated a significant reduction of the weight increase in rats. The Sibutramine group showed a significant reduction on blood glycemia compared to Rimonabant group and Control group. Conclusions: Rimonabant showed to be more effective than Sibutramine by decreasing weight gain. Sibutramine has been more effective than Rimonabant and Control groups by decreasing the blood glycemia.
\end{abstract}

Key words: Obesity. Drug Effects. Animal Experimentation. Rats.

\section{RESUMO}

Objetivo: Comparar o efeito do rimonabanto, nova droga seletivamente antagonista dos receptores CB1, com a sibutramina. Métodos: Ensaio clínico experimental, prospectivo, placebo controlado. Realizado com 38 ratas, adultas, submetidas a dieta hipercalórica. Foram coletadas 3 amostras de sangue e o peso controlado semanalmente. Foram divididas em 3 grupos: Rimonabanto, Sibutramina e Controle. Analise estatística realizada com ANOVA, teste $t$ de Student e teste de Tukey. Resultados: O grupo Rimonabanto obteve redução significante do ganho de peso. O grupo Sibutramina teve redução significativa da glicemia quando comparado aos demais grupos. Conclusões: Rimonabanto foi mais efetivo que a Sibutramina na redução do ganho de peso. A Sibutramina foi mais efetiva na redução da glicemia do que os grupos controle e Rimonabanto.

Descritores: Obesidade. Efeitos de Drogas. Experimentação Animal. Ratos.

${ }^{1}$ Research performed at Experimental Animal Laboratory, Lutheran University of Brazil (ULBRA), Canoas - RS, Brazil.

\section{Introduction}

World Health Organization classifies obesity as a global epidemic. For the first time in history, the number of people over weight has passed the number of those who are malnutrited (one billion and two hundred million in the world). These figures are alarming. Countries that were recently concerned with hunger and food scarceness already present an alarming increase of obese people. Brazil é a good example; one in every three Brazilians is already overweight ${ }^{1}$.

For a long time, obesity was considered a problem of wealthy people. It was believed that in countries in development the government had to worry with poverty and hunger only. In the last few years, while obesity is still growing fast in wealthy countries, a phenomenon called "nutritional transition" is happening in less developed countries. As misery is being eradicated among low budget populations, obesity arises as the most frequent and important public health problem and even more serious than malnutrition ${ }^{1}$.

The huge industrial food production, especially the ones ready to be consumed, and media empathizing cooking pleasures in television or on the web makes us trapped in this pattern. 
Genetic factors, individual and family intake habits and social conditioning collaborate for an inadequate behavior. It is the physician's duty to keep this subject as the first topic of discussion and concerns in order to have better solutions ${ }^{2}$.

Obesity by its features and multifactorial etiology is a condition that has gained attention and has been studied in several specialties, especially by psychiatry and psychology. However, in Diagnostic and Statistical Manual of Mental Disorders, fourth edition (DSM IV-TR) there are no criteria to identify and evaluate obesity as a psychiatric disorder, even in the eating disorders category, although its patients present behavior disorders and psychic conflicts that are food related. Even though obesity is not considered an eating disorder, some authors have included it didactically in this category by its similar aspects with eating disorders because it also has features of those disturbs, presenting psychological syndrome associated which might need psychiatric follow up ${ }^{3}$.

General goals of the treatment of eating disorders are: normal intake pattern, maintenance of expected weight for age and height, discontinue of restrictive and purgative measures, better self body image and solve alterations of psychological, social and family follow up of all affected by the disease ${ }^{4}$.

Obesity brings along other serious diseases: Tipe II diabetes, arterial hypertension, dyslipidemia, artrosis, hyperuricemia, arthrosis, tumors, sleep apnea, atherosclerosis, ischemic cardiophaty, psychiatric distress, premature death ${ }^{5}$.

It is known that weight loss of 5 to $10 \%$ of body weight is associated to less cardiovascular risk and reduces type II diabetes incidence ${ }^{6}$.

Current anti-obesity agents can be divided in two main groups: those that act in appetite modulation (anorexigen and appetite suppressant with effects noradrenergic and serotonergic, respectively) and those that promote the decrease of fat absorption by the intestine. Recent researches show that rimonabant, a cannabinoid receptor agonist, provides weight loss because acts in appetite modulation as well as acts directly in the peripheral adipose tissue ${ }^{7}$.

Sibutramine hydrochloride monohydrate is a drug used orally to treat obesity that leads to weight loss through a double mechanism: decrease of food intake by appetite modulation and appetite suppressant and preventing decrease of energetic burn followed by weight loss. Sibutramine is a powerful reuptake of serotonin, noradrenalin and dopamine inhibitor. It causes an impact in food intake increasing satisfaction feeling ${ }^{8}$.

Sibutramine has been appropriate for patients with periodic eating disorder which disorders in serotonergic system can result in depression associated to food compulsion episodes that are characteristic of periodic eating disorder. It is important to highlight that the drug is metabolized in the liver by the cytochrome enzyme system 450 (CYP3A4 isoenzyme) $)^{9}$.

The first specific agonist of endocannabinoid CB1 receptor was discovered in 1994 and was denominated as SR141716 or Rimonabant. This substrate has been studied as an appetite modulator and as agent to control tabagism and, especially, to control risk factors linked to visceral obesity. The $\mathrm{CB} 1$ is the most abundant GPCR receptor (G-protein-Coupled-Receptor) in the brain and peripheral nervous system. Attention must be paid when it is present in the adipose tissue ${ }^{10}$.

Endocannabinoid system is a physiologic system present in the brain and in peripheral tissues (including adipocytes) that affects energetic balance, lipid, glycide metabolism and body weight. Also regulates through the neurons of mesolimbic system food intake highly tasty like sugar and fats ${ }^{6}$.

This new product promotes a relative decrease of hunger, helps satisfying the appetite and induces more fat burn, especially visceral abdominal fat ${ }^{10}$.

This study aims to compare Rimonabant and Sibutramine effects in food intake and weight loss of rats and also to determinate the effects of these drugs on lipid and glycide profile.

\section{Methods}

This prospective experimental study was performed on 38 female adult Wistar rats weighting $145 \mathrm{~g}$ to $240 \mathrm{~g}$. They were maintained on a 12-h light-dark cycle in a temperature-controlled $\left(22^{\circ} \mathrm{C}\right)$ colony room and had free access to food and water. The experiments were performed according to the Guide for the care and use of laboratory animals, and the Ethics Committee for Experiments on Animals of ULBRA approved all procedures.

Three groups were studied:

Control group (14 rats) - received standard food + hypercaloric during eight weeks; using saline $(\mathrm{NaCl} 0.9 \%)$ as vehicle in the maintaining the same diet for the following 4 weeks.

Rimonabant Group (12 rats) $10 \mathrm{mg} / \mathrm{Kg} / \mathrm{day}$ (Sanofi-Aventis) - received standard food + hypercaloric during 8 weeks, Rimonabant was used for the following 4 weeks, maintaining the same diet.

Sibutramine Group (12 rats) $5 \mathrm{mg} / \mathrm{Kg} /$ day - received standard food + hypercaloric during 8 weeks, sibutramine was used for the following 4 weeks maintaining the same diet.

The gain weight diet (hypercaloric) was a mix of food: toasted peanut bars with sugar, commercial candy bars, chocolate cookie, granola and baconzitos. This diet composition contains pure protein, sugar, amid and fat in the following proportions: $5.6 \%$, $42.3 \%, 11.3 \%$ and $24 \%$ and the standard ration for rats contains $18.9 \%, 4.7 \%, 30.7 \%$ and $6.5 \%$ respectively. The energetic value of the hypercaloric diet was $452 \mathrm{Kcal} /$ week per rat. Rats of the control group received saline only.

The drugs were administrated via gavage in $\mathrm{NaCl} 0.9 \%$ in $5 \mathrm{ml} / \mathrm{Kg}$ of volume. Drug administration was made orally (gavage) through stainless steel tube (rigid). This tube reached the esophagus of the animal as follows: the head was immobilized, it was in the vertical position without immobilizing the rest of the body and the tube was introduced laterally in the mouth with a syringe attached to it until reaches the posterior wall of the mouth (throat). A movement moving the syringe towards the superior part of the mouth of the rat intending to make hyperextension of the neck, once no resistance was found, the tube was introduced more deeply.

Three blood draws were made, one in nocturne fast for collecting in the morning, via orbital cavity as follows: the animal was put down (volatile anesthetic was utilized) until complete immobilization. Heparinized capillary glass for microhematocrit. Blood was draw directly inside the tubes. This procedure was made as follows: the animal was put down and placed in ventral decubitus immobilizing the head with the left hand and pressuring it against the table. The capillary glass was introduced in the orbit with the right hand in $45^{\circ}$ to the nose in a horizontal plane and 
pressuring in circles to tear the orbital cavity membrane. When the cavity was reached, the blood flowed through the capillary of the tube allowing blood flow slowly in the tube walls. After the draw of the desired volume, the capillary was removed and digital pressure was made in the eye with help of gauze. The ocular globe had no harm.

These draws were made before the hypercaloric diet, before the beginning of the treatment, and after the treatment of the three groups for total cholesterol, triglycerides, HDL, LDL and glycemia by conventional biochemistry techniques.

At the end of the experiment the animals were sacrificed in a carbonic gas chamber and its bodies were wrapped in plastic bags and disposed in hazard waste.

\section{Statistical analysis}

Quantitative variables were described (average and standard deviation) and the groups were compared among each other by the ANOVA test. Later the Tukey test was made for multiple comparisons. The variables were compared inside each group moments before and after by the student $t$ test for paired samples. Groups were compared during the modifications as the time passed by variance analysis for repeated measures. The level of significance used was $5 \%(p<0.05)$.

\section{Results}

During the hypercaloric diet ( 8 weeks) the rats presented significant weight gain. Through the ANOVA method, the weight average in the beginning of the hypercaloric diet was $189.97 \mathrm{~g}$ and onset treatment was $283.94 \mathrm{~g}$ with $\mathrm{p}<0,001$ (Figure 1, Table 1). Comparative analysis of the three groups showed no statistical significant difference of variables: total cholesterol, HDL and LDL $(\mathrm{p}<0.05)$.

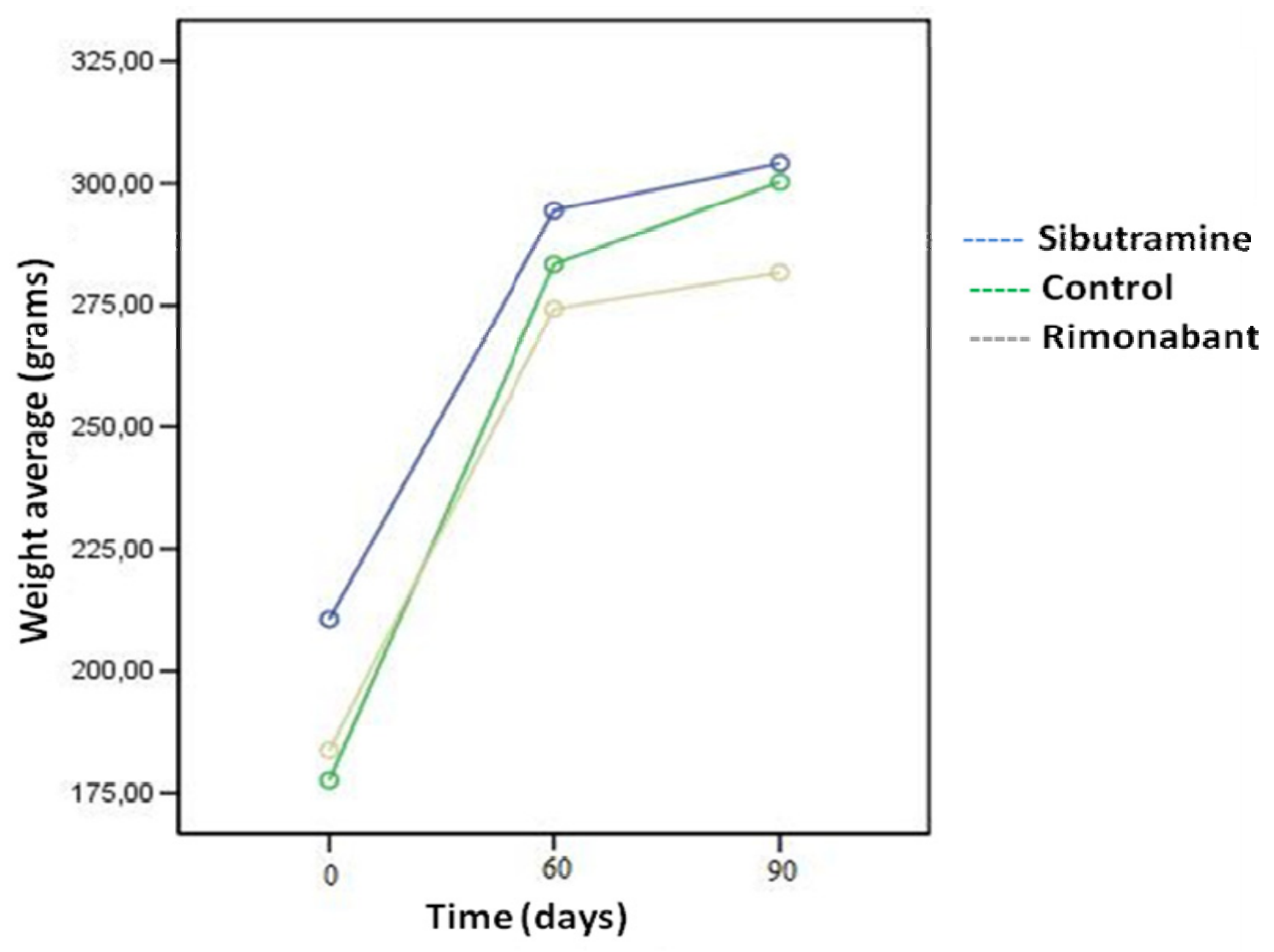

FIGURE 1 - Weight average comparison of three groups in hypercaloric diet on set, on set of drugs and at the end of treatment 
TABLE 1 - Comparison between the groups on set the treatment and after 60 days of hyper caloric diet

\begin{tabular}{lcccc}
\hline & Control (SD) & Sibutramine (SD) & Rimonabant (SD) & P \\
\hline Age/ Days & 111.71 & 112.16 & 110.33 & 0.848 \\
& $( \pm 7.48)$ & $( \pm 11.10)$ & $( \pm 4.69)$ & \\
Weight / Grams & 283.35 & 294.33 & 274.25 & 0.112 \\
& $( \pm 13.84)$ & $( \pm 21.23)$ & $( \pm 31.25)$ & \\
Glycose & 151.71 & 158.41 & 152.08 & 0.686 \\
& $( \pm 14.76)$ & $( \pm 25.82)$ & $( \pm 23.32)$ & \\
Total Cholesterol & 59.35 & 72.00 & 59.83 & $0.004^{*}$ \\
& $( \pm 10.69)$ & $( \pm 11.31)$ & $( \pm 6.76)$ & \\
HDL & 17.85 & 20.41 & 19.66 & 0.101 \\
& $( \pm 3.65)$ & $( \pm 3.50)$ & $( \pm 1.23)$ & \\
LDL & 25.42 & 35.75 & 25.50 & $0.006^{*}$ \\
Triglicerides & $( \pm 6.42)$ & $( \pm 12.22)$ & $( \pm 5.83)$ & \\
& 80.35 & 78.83 & 73.58 & 0.421 \\
\hline
\end{tabular}

* Sibutramine $\neq$ Control and Rimonabant in cholesterol e LDL variables.

Variables are described by average and compared by ANOVA test.

$\mathrm{SD}=$ Standard Deviation \pm

$\mathrm{p}=$ significance level.

According to the collected data, we can state that there was statistical significant difference in variables: weight and glycose of the animals studied. The weight variable had statistical significant difference between the Rimonabant group X control group ( $p=0.023)$ as displayed in Table 2 . The glycose variable had a decrease of glycose in the Sibutramine group, which was statistically significant when compared to the control group and the Rimonabant group $(\mathrm{p}=0.015)$ (Figure 2).

TABLE 2 - Comparison between on set and end of the treatment

\begin{tabular}{|c|c|c|c|c|c|c|c|c|c|c|}
\hline & \multicolumn{3}{|c|}{ CONTROL } & \multicolumn{3}{|c|}{ SIBUTRAMINE } & \multicolumn{3}{|c|}{ RIMONABANT } & \\
\hline & $\begin{array}{c}\text { Before } \\
\text { (SD) }\end{array}$ & $\begin{array}{l}\text { After } \\
\text { (SD) }\end{array}$ & p & $\begin{array}{c}\text { Before } \\
\text { (SD) }\end{array}$ & $\begin{array}{l}\text { After } \\
\text { (SD) }\end{array}$ & p & $\begin{array}{l}\text { Before } \\
\text { (SD) }\end{array}$ & $\begin{array}{l}\text { After } \\
\text { (SD) }\end{array}$ & $\mathbf{p}$ & $\underset{\substack{p \\
\text { Group } \\
\text { Integration }}}{\stackrel{p}{c}}$ \\
\hline Weight & $\begin{array}{c}283.35 \\
( \pm 13.84)\end{array}$ & $\begin{array}{c}300.28 \\
( \pm 18.27)\end{array}$ & 0.00 & $\begin{array}{c}294.33 \\
( \pm 21.23)\end{array}$ & $\begin{array}{c}304.10 \\
( \pm 24.42)\end{array}$ & 0.001 & $\begin{array}{r}274.25 \\
( \pm 31.25)\end{array}$ & $\begin{array}{c}281.66 \\
( \pm 28.81)\end{array}$ & 0.018 & $0.023^{*}$ \\
\hline Glycose & $\begin{array}{c}151.71 \\
( \pm 14.76)\end{array}$ & $\begin{array}{c}165.64 \\
( \pm 37.12)\end{array}$ & 0.177 & $\begin{array}{c}158.41 \\
( \pm 25.82)\end{array}$ & $\begin{array}{c}111.00 \\
( \pm 24.88)\end{array}$ & 0.002 & $\begin{array}{c}152.08 \\
( \pm 23.32)\end{array}$ & $\begin{array}{c}163.16 \\
( \pm 73.05)\end{array}$ & 0.645 & $0.015^{*}$ \\
\hline Cholesterol & $\begin{array}{c}59.35 \\
( \pm 10.69)\end{array}$ & $\begin{array}{c}62.00 \\
( \pm 7.79)\end{array}$ & 0.408 & $\begin{array}{c}72.00 \\
( \pm 11.31)\end{array}$ & $\begin{array}{c}77.33 \\
( \pm 13.54)\end{array}$ & 0.353 & $\begin{array}{c}59.83 \\
( \pm 6.76)\end{array}$ & $\begin{array}{c}74.41 \\
( \pm 8.63)\end{array}$ & 0.001 & 0.097 \\
\hline HDL & $\begin{array}{c}17.85 \\
( \pm 3.65)\end{array}$ & $\begin{array}{c}17.00 \\
( \pm 2.00)\end{array}$ & 0.443 & $\begin{array}{c}20.41 \\
( \pm 3.50)\end{array}$ & $\begin{array}{c}15.66 \\
( \pm 5.15)\end{array}$ & 0.019 & $\begin{array}{c}19.66 \\
( \pm 1.23)\end{array}$ & $\begin{array}{c}17.50 \\
( \pm 10.25)\end{array}$ & 0.491 & 0.395 \\
\hline LDL & $\begin{array}{c}25.42 \\
( \pm 6.42)\end{array}$ & $\begin{array}{c}24.21 \\
( \pm 4.72)\end{array}$ & 0.613 & $\begin{array}{c}33.62 \\
( \pm 11.87)\end{array}$ & $\begin{array}{c}30.62 \\
( \pm 8.36)\end{array}$ & 0.546 & $\begin{array}{c}25.50 \\
( \pm 5.83)\end{array}$ & $\begin{array}{c}30.91 \\
( \pm 7.48)\end{array}$ & 0.053 & 0.133 \\
\hline Triglycerides & $\begin{array}{c}80.35 \\
( \pm 15.04)\end{array}$ & $\begin{array}{c}104.28 \\
( \pm 32.85)\end{array}$ & 0.007 & $\begin{array}{c}78.83 \\
( \pm 14.05)\end{array}$ & $\begin{array}{c}186.41 \\
( \pm 101.51)\end{array}$ & 0.004 & $\begin{array}{c}73.58 \\
( \pm 10.25)\end{array}$ & $\begin{array}{c}129.75 \\
( \pm 59.90)\end{array}$ & 0.004 & 0.013 \\
\hline
\end{tabular}

Variables are described by average \pm (Standard Deviation) and compared by $t$ Student Test for paired samples.

$\mathrm{SD}=$ Standard Deviation

*Significance obtained by variance for repeated measures

Weight: The difference was seen between Rimonabant group X Control Group.

Glucose: The difference was seen between Sibutramine group X Control Group and Sibutramine group X Rimonabant group.

$\mathrm{p}=$ Significance level. 


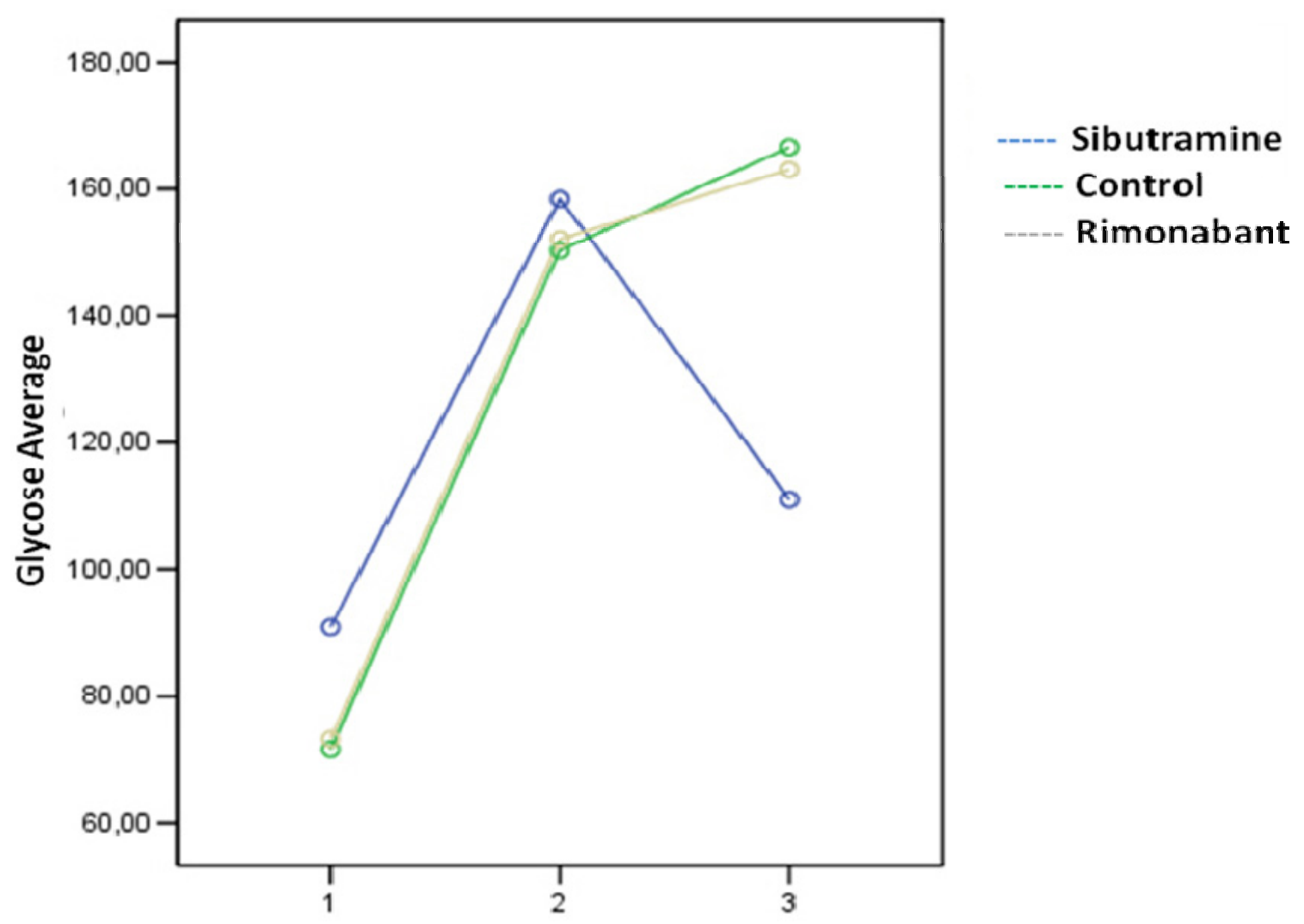

FIGURE 2 - Glycose comparison at the three phases of the study. There was significant decrease in Sibutramine group

\section{Discussion}

According to Repetto? "facing recent obesity pandemia and the difficulty in changing life style, pharmacological therapy to treat obesity is indicated. It must be clear that the first goal in obesity treatment is to reduce morbid and mortality associated to overweight and improve life quality of the obese patient. The choice of the better agent to be indicated must come from a careful evaluation of important points such as: age of the patient, associated morbidies, drug interaction, presence of eating disorder or depression, financial aspects, side effects, risk of addiction, among others. It is extremely relevant to have the patient's conscience about the need of long term treatment, aiming the maintenance of the weight loss".

The special diet with high fat concentrations and carbohydrates induces obesity in rats producing a phenotype similar to the human obesity syndrome and dyslipidemia.

The pharmacotherapy of periodic eating disorder is a field that have experimented a promising development in the last few years. Pharmacological studies made in periodic eating disorder have presented progressive refinement. Periodic eating disorder is a clinical entity emergent that responds to pharmacological treatment.

Aiming pharmacological aid to treat obesity, this work is inside the most modern pharmacological parameters.

Rimonabant ${ }^{11}$ is the first $\mathrm{CB} 1$ receptor select agonist because it is a new drug in the market and has little time of clinical use and still needs tests comparing to other preexisting drugs, that is the reason why this research was elaborated.

Rucker et $a l .{ }^{12}$ study concluded that Rimonabant decreased HDL concentrations and triglycerides more, although increased blood pressure and heart rate. Rimonabant improved HDL concentrations and triglycerides, blood pressure and glycemia in diabetic patients. In the present study Rimonabant showed to be more effective than Sibutramine to reduce weight gain, similar to Rucker et al. ${ }^{12}$ study, although Sibutramine showed to be more effective regarding the reduction of glycemia.

Bronander and Bloch ${ }^{13}$ showed the efficacy of Rimonabant in the increase of HDL, reducing triglycerides, decreasing insulin levels and improving glycose in diabetic patients which did not occurred in this research regarding the lipid profile.

Nisoli and Carruba ${ }^{14}$ described that patients that are using Sibutramine did not present statistical significance for glycemic control despite the fact that they have demonstrated mild decrease of glycemia. They demonstrated sibutramine efficacy in the onset of weight loss and maintenance of this loss in two years of this clinical trial. In this study there was no weight loss in rats using sibutramine, however, there was a significant reduction related to glycose just like occurred in the Fias et al. ${ }^{15}$ work.

Christensen et al. ${ }^{6}$ showed in meta-analysis that rimonabant reduces in average $10 \%$ of body weight in one year of treatment compared with a placebo and suggests that is similar or even better than other drugs anti-obesity that already exists, such as sibutramine. 
In the study made by Vickers et al. ${ }^{16}$ it was demonstrated that sibutramine reduces significantly food intake and increases the weight in rats. This result was not seen in our experiment, although can be perceived a tendency to weight loss.

During the experiment was observed that the groups which were taking the drugs do not consumed all food offered when compared to control group, which consumed all food in a period of 24 hours. It was noticed that female rats of rimonabant group became more agitated, making its management more difficult. Also, it was observed that the feces became pastier when compared to the control group and sibutramine group. This observation can be a data a future study aiming scientific clearance.

\section{Conclusions}

Rimonabant was more effective in reduction of weight gain when compared to the control group and sibutramine group.

In the sibutramine group had considerable decrease of weight gain when compared to the control group. A significant decrease of glycemia occurred in the sibutramine group.

\section{References}

1. Coutinho W. Estudo da compulsão alimentar periódica em pacientes que procuram tratamento médico para emagrecer [Tese]. Universidade Federal de São Paulo; 2000.

2. Silveira TR, Silva LCC. Editorial. Bol Cient AMRIGS. 2008;1-4.

3. Flaherty D, Janicak PG. Psiquiatria, diagnóstico e tratamento. Porto Alegre: Artes Médicas; 1995.

4. Salzano FT. Tratamento de transtornos alimentares em hospital-dia. Boletim de Transtornos Afetivos e Alimentares (BOTA). 2000;11:03.

5. Friedman R. A epidemia chegou. Bol Cient AMRIGS. 2008;2:1.

6. Christensen R, Kristensen PK, Bartels EM, Bliddal H, Astrup A. Efficacy and safety of the weight-loss drug rimonabant: a meta-analysis of randomised trials. Lancet. 2007; 370(9600):1706-13.
7. Repetto G. Tratamento farmacológico da obesidade. Bol Cient AMRIGS. 2008; 2:3.

8. Ballone GJ. Tratamento psiquiátrico da obesidade. Disponível em: www.psiqweb.med.br [Acesso em: 09, mar,2008]

9. Zanella MT. Síndrome metabólica e depressão. Comorbidades depressão e síndrome metabólica UNIFESP. Agosto 2008, 03-06.

10. Mattos AG, Guedes EP, Souza LL, Valério CM. O Sistema endocanabinóide: novo paradigma no tratamento da síndrome metabólica. Arq Bras Endocrinol Metab. 2006; 50(2):390-9.

11. Herling AW, Kilp S, Elvert R, Haschke G, Kramer W. Increased energy expendure contributes more to the body weight reducing effect of rimonabant than reduced food intake in candy-fed Wistar rats. Endocrinology. 2008;149:2557-66.

12. Rucker D, Padwal R, Li SK, Curioni C, Lau DCW. Long term pharmacotherapy for obesity and overweight: updated meta-analysis. BMJ. 2007;335:1194-9.

13. Bronander A, Bloch C. Potential role of the endocannabinoid receptor antagonist rimonabant in the management of cardiometabolic risk: a narrative review of available data. Vasc Health Risk Manag. 2007;3(2):181-90.

14. Nisoli E, Carruba MO. A benefit-risk assessment of sibutramine in the management of obesity. Drug Safety. 2003;26(14):1027-48.

15. Fisas A, Codony X, Romero G, Dordal A, Giraldo J, Mercé R, Holenz J, Vrang N, Sørensen RV, Heal D, Buschmann H, Pauwels PJ. Chronic 5-HT6 receptor modulation by E-6837 induces hypophagia and sustained weight loss in diet-induced obese rats. Br J Pharmacol. 2006;148(7):973-83.

16. Vickers SP, Webster LJ, Wyatt A, Dourish CT, Kennett GA. Preferential effects of the cannabinoid CB1 receptor antagonist, SR 141716, on food intake and body weight gain of obese (fa/fa ) compared to lean Zucker rats. Psychopharmacology (Berl). 2003;167(1):103-11.

\section{Acknowledgement}

We are grateful to Gabriela dos Santos Santana for the technical assistance in the care of animals.

Conflict of interest: none Financial source: none

\section{Correspondence:}

Prof. Honório Sampaio Menezes

Instituto de Cardiologia do Rio Grande do Sul/FUC

Av. Princesa Isabel, 370

90620-001 Porto Alegre - RS Brazil

Phone/Fax: (55 51)3219-2802

hsmenezes@computech.com.br

Received: April 15, 2009

Review: June 16, 2009

Accepted: July 17, 2009

\section{How to cite this article}

Menezes HS, Ciulla V, Camargo PS, Correa CA, Oliveira TMC. Comparison of rimonabant and sibutramine treatment effects on food compulsion in rats. Acta Cir Bras. [serial on the Internet] 2009 Nov-Dec;24(6). Available from URL: http://www.scielo.br/acb 